http://jmscr.igmpublication.org/home/ ISSN (e)-2347-176x ISSN (p) 2455-0450

crossref DOI: https://dx.doi.org/10.18535/jmscr/v8i1.141

\title{
Relationship of Radiological Abnormalities and the Level of Pain in Patients with Knee Joint Osteoarthritis in Kendari City General Hospital
}

\section{Muh Rustam HN ${ }^{1}$, Agussalim Ali ${ }^{2}$, Iis Ainu Rahma ${ }^{3}$, La Ode Alifariki ${ }^{*}$}

${ }^{1}$ Department of Medical, Medical of Faculty, Halu Oleo University, Indonesia

${ }^{2}$ Department of Epidemiologi, Medical of Faculty, Halu Oleo University, Indonesia

*Corresponding Author

\section{La Ode Alifariki}

\begin{abstract}
Background: The aims of this study determine the correlation between radiological abnormalities staging and pain level with osteoartritic of knee joint of Rumah Sakit Umum Daerah Kota Kendari.

Method: This research is an observational analytic study with cross-sectional approach. 37 samples were acquired through total sampling. Data were analyzed using the Spearman correlation test ( $p$ value $<0,05$ ).

Result: Result of the univariat analysis show that most patients have moderat radiological abnormality that was 12 (32.43\%) and most of patient have severe pain level that was19 (51.35\%). Based on bivariat statistical test, a positive correlation was obtained between radiological abnormalities staging and pain level with osteoartritic of knee joint with $p=0,000$ and $r=0,831$.

Conclusion: There was a significant correlation between radiological abnormalities staging and pain level with osteoartritic of knee joint of Rumah Sakit Umum Daerah Kota Kendari.
\end{abstract}

Keywords: Osteoarthritic, Radiological abnormalities staging, Pain level.

\section{Introduction}

Osteoarthritis (OA) is one of the 10 main causes of disorders of joint movement. Osteoarthritis may cause the quality of life OA sufferers to decrease ${ }^{[1]}$. It is estimated that $\mathrm{OA}$ will be the fourth highest in 2020 as a disease causing disability in the world ${ }^{[2]}$. Osteoarthritis is one of the most common forms of arthritis affecting $15 \%$ of the world's population, which usually affects the joints (knee joints) ${ }^{[3]}$.

OA sufferers generally complain of pain when doing daily activities, work related to loading on the affected joints ${ }^{[4],[5]}$. Severe pain can occur continuously, which greatly interferes with the patient's mobility.

According to the American College of Rheumatology, the diagnosis of OA refers to knee pain and osteophytes on X-ray images, as well as at least one of these signs and symptoms at more than
50 years of age, joint stiffness in the morning less than 30 minutes and the presence of crepitations during physical examination ${ }^{[6]}$.

Joint pain is usually the main complaint of patients when visiting a doctor. OA radiographic classification according to Kellgren-Lawrence criteria shows Level 0 shows an abnormal radiographic picture. Level 1 is doubtful, osteophytes appear in small size. Level 2 is minimal, looks osteophyte, normal joint gap. Moderate is grade 3, clear osteophytes, narrowing of joint gaps. A level 4 is severe, narrowing of severe joint gap and the presence of sclerosis ${ }^{[6]}$.

Geno osteoarthritis is a major cause of morbidity, impaired physical activity and reduced quality of life for osteoarthritis sufferers, especially at the age of 45 years and above. Osteoarthritis has a significant impact on social and economic life ${ }^{[7]}$. 
The prevalence of OA at 61 years old in Indonesia reaches $5 \%$. The prevalence of joint disease in Indonesia is based on diagnosis by health professionals, which is $11.9 \%$ and based on symptoms of $24.7 \%$. Female OA sufferers are the most $(27.5 \%)$ compared to men $(21.8 \%)^{[8]}$.

Based on data at the Kendari City General Hospital in 2018, the estimated number of outpatients with osteoarthritis was 266 in 2017 and in 2018 January to August there were 211 patients $^{[9]}$.

Based on research conducted by ${ }^{[10]}$ about the relationship of the level of pain with the level of radiologic abnormalities of osteoarthritis patients at Tugurejo Regional Hospital Semarang, the results show that there is a relationship between the level of pediatricita's radiological abnormalities and the level of pain in genuary osteoarthritis sufferers.

Therefore, osteoarthritis was chosen as the object of this study because of the increasing prevalence of osteoarthritis in Indonesia, including in Southeast Sulawesi. Researcher are interested to see the relationship between the level of radiological abnormalities and the level of pain in patients with osteoarthritis of the knee joint in the Kendari City General Hospital.

\section{Material and Methods}

This type of research is observational analytic with cross sectional approach. The research was conducted in November to December 2018 at the Orthopedy Polytechnic of the Kendari City Regional General Hospital and at the homes of respondents. The sampling technique in this study was a total sampling of 37 respondents out of 37 respondents who were diagnosed with osteoarthritis in poly orthopedics in Kendari City Hospital.

Primary data collection is done by filling out research forms and pain assessment instruments to respondents. Data analysis was performed using the Spearman statistical test, with a $p$ value $<0.05$ with the help of SPSS 16. This study was approved by the Health Research Ethics Commission of the Research Institute and Community Services at the University of Halu Oleo.

\section{Findings}

\section{Characteristics of Research Samples}

Table 1 in this study shows the frequency distribution of research components including gender, age, BMI, level of pain and level of radiologic abnormalities with the number of samples in this study were 37 respondents.

Of the total sample, samples with male gender are as many as $10(27 \%)$ people and samples with female gender are as many as 27 (73\%) people. Thus it is known that the majority of research samples are female. In the age group of the middle elderly (56-65 years).as many as 18 respondents (48.6\%)

In measuring the level of pain, there were $6(16.2 \%)$ people with mild pain, $12(32.4 \%)$ moderate pain and $19(51.4 \%)$ severe pain. Thus it is known that the majority of study samples experienced severe pain.

The results of the measurement of the level of radiological abnormalities of patients with osteoartitis of the knee joint were found in 10 $(27.0 \%)$ samples of people with dubious radiological abnormalities (level 1), minimal radiological abnormalities (level 2) as many as 9 $(24.3 \%)$ people, moderate level of abnormality radiologic (level 3) 12 (32.4\%) people, and severity of radiologic abnormalities (level 4) 6 (16.2\%) people. Thus, the majority of the study sample had moderate levels of radiologic abnormalities.

Table 1 Distribution of sample characteristics based on sex, age, BMI, level of pain and level of radiological abnormalities in Kendari City Hospital

\begin{tabular}{|c|c|c|c|}
\hline No. & Variabel & $\begin{array}{l}\text { Frequency } \\
\text { (n) }\end{array}$ & $\begin{array}{c}\text { Percentage } \\
(\%)\end{array}$ \\
\hline \multirow[t]{3}{*}{1.} & Gender & & \\
\hline & Male & 10 & $27 \%$ \\
\hline & Female & 27 & $73 \%$ \\
\hline \multirow[t]{4}{*}{2.} & Pain Level & & \\
\hline & Mild = NRS 1-3 & 6 & $16,2 \%$ \\
\hline & Moderate = NRS 4-6 & 12 & $32,4 \%$ \\
\hline & Severe $=$ NRS 7-10 & 19 & $51,4 \%$ \\
\hline \multirow[t]{5}{*}{3.} & $\begin{array}{l}\text { Level of Radiology } \\
\text { abnormalities }\end{array}$ & & \\
\hline & Level 1= Doubting & 10 & $27,0 \%$ \\
\hline & Level 2= Minimal & 9 & $24,3 \%$ \\
\hline & Level 3=Average & 12 & $32,4 \%$ \\
\hline & Derajat 4=High & 6 & $16,1 \%$ \\
\hline & Total & 37 & $100 \%$ \\
\hline
\end{tabular}




\section{Bivariate analysis}

The relationship between the level of radiological abnormalities with the level of pain in patients with osteoarthritis of the knee joint in the City Hospital of Kendari.

Based on Table 2, shows the samples that experienced doubtful levels of radiological abnormalities (grade 1) and the level of mild pain were as many as $5(50 \%)$ people. Samples with dubious radiological abnormalities (grade 1) and moderate pain levels were present in $5(50 \%)$ people. Samples that experienced minimal levels of radiological abnormalities (level 2) and mild pain levels were as many as $1(11.1 \%)$ people. Samples that experienced minimal levels of radiologic abnormalities (level 2) and moderate pain levels were present in $6(66.6 \%)$ people. Samples who experienced minimal levels of radiological abnormalities (level 2) and severe pain levels were as many as $2(22.2 \%)$ people. Samples who experienced moderate levels of radiological abnormalities (grade 3) and moderate pain levels were present in $1(8.3 \%)$ person. Samples who experienced level of radiological abnormalities (level 3) and level of severe pain were as many as $11(91.6 \%)$ people. Samples who experienced severe levels of radiological abnormalities (level 4) and levels of severe pain were as many as $6(100 \%)$ people.

Table 2 Analysis of the relationship between levels of radiological abnormalities with the levels of pain in patients with osteoarthritis of the knee joint in the Kendari City Hospital

\begin{tabular}{|c|c|c|c|c|c|c|c|c|c|c|}
\hline \multicolumn{2}{|c|}{ Bivariate analysis } & \multicolumn{6}{|c|}{ Level of Pain } & \multicolumn{2}{|c|}{ amount } & \multirow{3}{*}{$\begin{array}{l}\text { Spearman } \\
\text { test }\end{array}$} \\
\hline & & \multicolumn{2}{|c|}{ Mild } & \multicolumn{2}{|c|}{ Moderate } & \multicolumn{2}{|c|}{ Severe } & & & \\
\hline & & $\mathbf{n}$ & $\%$ & n & $\%$ & n & $\%$ & $\mathbf{n}$ & $(\%)$ & \\
\hline \multirow{4}{*}{$\begin{array}{l}\text { Level of } \\
\text { Radiological } \\
\text { abnormalities }\end{array}$} & $\begin{array}{l}\text { Doubting } \\
\text { (Level 1) }\end{array}$ & 5 & 50 & 5 & 50 & 0 & 0 & 10 & 100 & \multirow[t]{5}{*}{$\begin{array}{l}\mathrm{P}=0,000 \\
\mathrm{r}=0,831\end{array}$} \\
\hline & $\begin{array}{l}\text { Minimum } \\
\text { (Level 2) }\end{array}$ & 1 & 11,1 & 6 & 66,6 & 2 & 22,2 & 9 & 100 & \\
\hline & $\begin{array}{l}\text { Average } \\
\text { (Level 3) }\end{array}$ & 0 & 0 & 1 & 8,3 & 11 & 91,6 & 12 & 100 & \\
\hline & $\begin{array}{l}\text { High } \\
\text { (Level 4) }\end{array}$ & 0 & 0 & 0 & 0 & 6 & 100 & 6 & 100 & \\
\hline \multicolumn{2}{|l|}{ Total } & 6 & 16,2 & 12 & 32,4 & 19 & 51,3 & 37 & 100 & \\
\hline
\end{tabular}

Based on the data in table 2, it can be stated there is a relationship between the level of radiological abnormalities with the level of pain in patients with osteoarthritis of the knee joint in the General Hospital of Kendari City with the Spearmen test showing the results in the form of significance values $\mathrm{p}=0,000$ and $\mathrm{r}=0.831$.

\section{Discussion}

This study shows that osteoarthritis of the knee joint is higher in women compared to men. The results of this study are in line with research conducted by ${ }^{[11]}$ which states that OA patients are $68.3 \%$ more female than male OA patients with a percentage of $56.8 \%$. From these figures it can be seen that the incidence of knee OA tends to be experienced by women. This is in line with the concept of the theory that as a whole at the age of 50 years, the frequency of OA is more common in women (after menopause) which shows hormonal factors that also play a role in the incidence of OA.

This study shows that the majority of knee joint OA patients experience severe pain with a percentage of $51.4 \%$. The results of this study are in line with the study of Elen Mahmud Lakum (2011) who got results on knee OA patients with severe pain by $50.5 \%$ more than moderate pain which was $48.5 \%$.

The most common level of radiological abnormalities in this study was at level 3 moderate (32.4\%), followed by level 1 doubts (27\%), minimal level 2 (24.4\%), level 4 severe $(16.2 \%)$. These results are in line with research conducted by ${ }^{[12]}$ who obtained the highest level of radiological abnormalities at level 3 (moderate) with a percentage of $61.4 \%$. 
This study shows that there is a relationship between the level of radiologic abnormalities with the level of pain in patients with osteoarthritis of the knee joint which can be seen at a significance value of $p=0,000(<0.05)$ with a correlation coefficient $r$ $=0.831$ which indicates a positive correlation. These results are in line with research conducted by[10] with the Chi-Square Test showing the value of $\mathrm{p}=0,000(<0.05)$ and research conducted by ${ }^{[13]}$ with the results of the spearman test showing the correlation coefficient (r) equal to 0.58 with probability $(\mathrm{p})=0.001$. It can also be interpreted that the higher the level of radiologic abnormalities, the higher the level of pain.

Pathophysiologically osteophytes cause the periosteal reaction and nerve suppression and directly cause pain and decrease the size of the femorotibia joint gap from normal size. Increased intramedullary pressure, subchondra fracture may also trigger pain ${ }^{[10]}$.

Osteoarthritis is a degenerative joint disease with slow progressive development which has a characteristic pathological picture in the form of worsening of joint cartilage as a result of biochemical, metabolic, physiological and pathological changes ${ }^{[14]}$.

Types of pain in osteoarthritis sufferers include nonneurogenic musculoskeletal pain, also known as altralgia, which is pathogenic pain in the joints. The mechanism of pain in OA occurs due to a pathological condition that affects cartilage and joints, where osteophyte formation occurs in joint cartilage and subchondaral tissue which causes a decrease in joint elasticity. In addition to the joint surface (joint cartilage), it also affects areas around the joint such as the subchondral bone, capsule ligament that encloses the joint and the muscles that are attached close to the joint. Changes that occur on the surface of the joints (hyalincartilago) associated with biochemical changes below the surface of the cartilage that increases the synthesis of thymidine and glycine ${ }^{[15]}$.

This initial lesion is followed by progressive destruction of the cartilage. As a result of the imbalance between regeneration and degeneration, there will be softening, splitting and peeling of the joint-prone layers that will be released as corpus libera which can cause locking when the joints move ${ }^{[15]}$.

An increase in firbrinolytic activity in patients with OA causes a buildup of thrombus and lipid complexes in subcondra veins which causes ischemia and necrosis of subcondra tissue. The release of chemical mediators such as prostaglandin and inteleukin will cause bone angina through subcondra known to contain sensible nerve endings that can deliver pain because the tissue will release $\mathrm{K}+$ and intracellular protein ${ }^{[6]}$.

Increased levels of $\mathrm{K}+$ in extracellular will cause depolarization of nociceptors and protein in some circumstances will infiltrate microorganisms causing inflammation. As a result, pain mediators are released such as leukotrin, prostaglandin E2, and histamine will stimulate the nociceptor, so that the transduction process occurs, the afferent nerve process translates the stimulus in the nociceptive impulse and then the transmission process is continued. Amplification of neural signals related to pain and perception processes occur in the brain ${ }^{[6]}$.

In the subchondral bone the process of repair is in the form of sclerosis with increased bone activity and the formation of spurs on the edges of joints that can limit movement ${ }^{[16],[17]}$. The bones under the cartilage become hard and thick and there is a change in the shape and suitability of the joint surface. If the damage continues then the shape of the joint becomes irregular with the narrowing of the joint gap, osteophytes, instability and deformity $^{[10]}$.

With the formation of osteophytes it will irritate the synovial membrane where there are many pain receptors and this will cause hydrops ${ }^{[1]}$. Due to the exposure of polymodal nerve endings that are around the joints due to the formation of osteophytes that suppress the periosteum and nerve roots from the spinal cord, and the swelling and thickening of soft tissue around the joints and increased intamedullar pressure due to static intramedullary veins due to the remodeling process in 
the trabeculae and subcondra, will cause tenderness and motion pain ${ }^{[10]}$.

\section{Conclusion}

Based on the results of this study, it can be concluded that the majority of sufferers of knee joint OA in Kendari City General Hospital experienced moderate level (level 3) radiological abnormalities (32.4\%), severe pain level (NRS 7-10) of $51.4 \%$ and there is a significant relationship between the level of radiological abnormalities with the level of pain in patients with osteoarthritis of the knee joint in the Kendari City General Hospital with a significance value of $\mathrm{p}=0,000(<0.05)$ with a correlation strength of $r=0.831$. Health services should provide counseling to patients to avoid risk factors for osteoarthritis and factors that can affect patient pain levels. For the people, they should always get used to a healthy life that is exercising regularly, losing weight if overweight, consuming healthy food and drinks to avoid all kinds of diseases, both infectious and non-communicable diseases. For future researchers, in order to be able to continue this research by adding other independent variables to look for other risk factors associated with the degree of pain in patients with osteoarthritis.

\section{Conflict of Interest}

In this study there is no conflict of interest

\section{Source of Funding}

This research uses private funds

\section{Ethical Clearance}

This study has received an ethics permit from the Health Research Ethics Commission from Halu Oleo University with number: 456/UN29.20/PPM/2019

\section{References}

1. C. Driscoll et al., "Nociceptive Sensitizers Are Regulated in Damaged Joint Tissues, Including Articular Cartilage, When Osteoarthritic Mice Display Pain Behavior," Arthritis Rheumatol. (Hoboken, N.J.), vol. 68, no. 4, pp. 857-867, Apr. 2016.
2. Anisa Ika Pratiwi, "DIAGNOSIS AND TREATMENT OSTEOARTHRITIS," Med. J. Lampung Univ., vol. 4, no. 4, pp. 10-17, 2015.

3. Y. Zhang and J. M. Jordan, "Epidemiology of osteoarthritis," Clin. Geriatr. Med., vol. 26, no. 3, pp. 355-369, Aug. 2010.

4. N. Kertia, "Status gizi berhubungan positif dengan derajat nyeri sendi penderita osteoartritis lutut," J. Gizi Klin. Indones., vol. 8, no. 3, pp. 144-150, 2012.

5. D. Bhatia, T. Bejarano, and M. Novo, "Current interventions in the management of knee osteoarthritis," J. Pharm. Bioallied Sci., vol. 5, no. 1, pp. 30-38, Jan. 2013.

6. M. Bahrudin, "Patofisiologi nyeri," J. Fak. Kedokt. Univ. Muhammadiyah Malang, vol. 13, no. 1, pp. 8-13, 2017.

7. M. C. Hochberg et al., "American College of Rheumatology 2012 recommendations for the use of nonpharmacologic and pharmacologic therapies in osteoarthritis of the hand, hip, and knee.," Arthritis Care Res. (Hoboken)., vol. 64, no. 4, pp. 465-474, Apr. 2012.

8. [Kementerian Kesehatan Republik Indonesia, Riset Kesehatan Dasar. Jakarta: Balitbangkes RI, 2013.

9. RSUD Kota Kendari, Osteoartritis. Kendari: Rekam Medik dan SIRS RSUD Kota Kendari, 2018.

10. M. R. Irza, "hubungan tingkat nyeri dengan tingkat kelainan radiologis pasien osteoartritis di Rumah Sakit Regional Tugurejo Semarang," Universitas Muhammadiah Semarang, 2016.

11. Wan Amin Hasiibi Bin Wan Ali, "Prevalensi Dan Distribusi Osteoartritis Lutut Berdasarkan Karakteristik Sosiodemografi Dan Faktor Resiko Di Wilayah Kerja Puskesmas Susu 1, Kecamatan Susut, Kabupaten Bangli Pada Tahun 2014," Universitas Udayana, 2014.

12. L. Chou et al., "Patients' perceived needs of osteoarthritis health information: A 
systematic scoping review," PLoS One, vol. 13, no. 4, p. e0195489, Apr. 2018.

13. E. M. Lukum, "Hubungan Derajat Nyeri Berdasarkan Visual Analogue Scale (VAS) Dengan Derajat Radiologik Berdasarkan Kellgren Lawrence Score Pada Foto Konvensional Lutut Pasien Osteoartritis Sendi Lutut.” 2011.

14. M. Maulina, "Kerusakan Proteoglikan Pada Osteoartritis," J. Ilm. Sains, Teknol. Ekon. Sos. dan Budaya, vol. 1, no. 1, pp. 61-67, 2017.

15. M. Irfan and R. Gahara, "Beda Pengaruh Penambahan Long Axis Oscillated Traction Pada Intervensi MWD Dan TENS Terhadap Pengurangan Rasa Nyeri Pada Capsullar Pattern Akibat Osteoartritis Lutut," $J$. Fisioter. Indonusa, vol. 6, no. 1, pp. 25-35, 2006.

16. G. S. Man and G. Mologhianu, "Osteoarthritis pathogenesis - a complex process that involves the entire joint," $J$. Med. Life, vol. 7, no. 1, pp. 37-41, Mar. 2014.

17. G. Li et al., "Subchondral bone in osteoarthritis: insight into risk factors and microstructural changes," Arthritis Res. Ther., vol. 15, no. 6, p. 223, 2013. 